\title{
Eesti regivärsi parallelism ja maagilise elutunde taandumine ${ }^{1}$
}

\author{
Jaan Undusk
}

Tahaksin oma iseenesest ju väga visandlikuks jäävas ning võimalikke tõsisemaid diskussioone ehk ainult tagant tõugata püüdvas arutluses ühte kimpu siduda sääraseid mõisteid ja nähtusi nagu eesti vanem ehk regivärsiline rahvalaul koos temale vormiliselt iseloomuliku parallelismi ehk mõtteriimiga, maagiline elutunne ja sellele vastav keelekasutustüüp ning animistlik ehk hingedeusku maailmavaade. Minu põhitees on õieti väga lihtne: ma väidan, et rahvalaulu parallelistlikul ülesehitusprintsiibil on mingi olemuslik side maagilis-animistliku maailmavaate ja sellele omase keelekasutusega.

Sedalaadi riskantset väidet välja käies ei pea - nagu see muidu tavaline - mitte kellelegi otseselt vastu vaidlema (ja see on asja meeldivam pool), sest küsimust säärasel kujul ei ole kas lihtsalt püstitatud või on see toimunud folkloristika ja lingvistika jaoks kauges spekulatiivses perifeerias. Parallelismiga ongi tegeldud valdavalt empiirialähedases perspektiivis, andes talle poetoloogilisi iseloomustusi neis piires, nagu ta keelelise nähtusena otse silmaga seiratavalt meie ees avaneb. Kõige kaugemale on jõutud mõtteriimi-ilmingute süstematiseerimises ja mudeldamises lingvistilis-loogiliste vahenditega, enamasti küll nende raamesse pidama jäädeski, kitsamatest erialastest järeldustest igaks juhuks eemaldumata. Siiski, Wolfgang Steinitzi (1934) ja Roman Jakobsoni (1966) klassikaliste käsitluste kõrvale võib häbitundeta asetada ka kodumaist parallelismiklassikat, olgu siis Jaan Kaplinski (1972) või Helle Metslangi (1981) sulest. Kummaski neis ei piirduta lingvistilise struktuurianalüüsiga, vaid tehakse oletusi keelelise parallelismi üldkultuuriliste aluste ja funktsiooni kohta, seda nii esteetilises kui ka filosoofilises plaanis, jõudes sellise mõtestustaseme lävele, kus peamiseks kujunevad juba niiöelda viimsed riskantsed küsimused laadis, miks ja millal üks või teine keelekultuurinähtus üldse maailma on siginenud. Eriti just J. Kaplinski artiklit võib pidada heaks näiteks sellest, kuidas hoida lingvistilise analüüsi juures elav filosoofiline alatoon, mis küsib pidevalt asjade kaugemate põhjuste järele.

http://haldjas.folklore.ee/tagused/nr24/undusk.pdf 


\section{Jaan Undusk}

Samas ei ole mulle kätte puutunud käsitlusi parallelismi võimalike religioonifilosoofiliste seoste kohta, kui maha arvata mõned põgusad vihjed. Kahe valdkonna ühendusteed on siin kahtlemata veelgi pikemad ja riskantsemad ning interdistsiplinaarset sillaehitajat ähvardab igal sammul diletandi aupaiste. Enamasti jääb folklorist igaks juhuks oma parallelismi, usundiloolane oma animismi ja maagia juurde, püüdes vältida uurimisobjektide kattumisi ja ühes sellega süüdistusi võimalikus ebapädevuses. Nii pole ka mõeldamatu, et suletakse erialalisse isolatsiooni nähtusi, mida kunagi võib olla iseloomustanud orgaaniline seong. Siiski sedastab näiteks Aleksandr Vesselovski kohe oma mõjuka parallelismikäsitluse (1898) esimeses lõigus, et parallelismi võiks nimetada animistliku maailmavaate ladestuseks poeetilises stiilis (Vesselovski 1989: 101). Ka alati julge mõttelennuga, söakalt interdistsiplinaarsetes vahekihtides sõeluva Oskar Looritsa töödes võib leida algeid parallelismi usundilooliseks läbivalgustamiseks. O. Looritsa järjekindlalt animistlik lähenemisviis eesti vanema rahvakultuuri ilmingutele, tema sügav veendumus, et selle kultuuri aluspõhi on hingedeusklik, veendumus, millega seltsib veel oskus oma vaateid kirglikult ja hästi töötava materjalihulga varal kaitsta, on siinkirjutajale üldse olnud vaimult lähedane, kuigi $\mathrm{O}$. Looritsal otsene keelefilosoofiline huvi puudub. Looritsa jaoks esindab eesti vanem rahvakultuur enamvähem selgelt maagilist kultuuritüüpi, ning seesama on ka siinkirjutaja lähe.

Kohe arutluse algul tuleb selgeks teha see, mida mõistetakse alljärgnevalt üldse maagilise elutunde, maagilise maailmavaate, maagilise kultuuritüübi või lihtsalt maagia all. Põhjalikumalt olen esitanud oma vaatekoha raamatus Maagiline müstiline keel (Undusk 1998), hingedeusuga seoses ka essees "Kuidas tsentreerida lõpmatust" (Undusk 1999), mistõttu siinkohal pruugib korrata vaid mõningaid kokkuvõtvaid lauseid. Tuleb silmas pidada, et väga tooniandev, ehkki hiljem mitut moodi nüansseeritud, on maagia kui kultuurinähtuse mõistmisel olnud James George Frazeri algatatud vaatekoht, õieti vaatekohtade pikaks veniv sari, mis seisneb lihtsamalt öeldes järgnevas: kui religioosne inimene usub mingit kõrgemalseisvat jõudu, kes valitseb teda, inimest, siis usub maag, et tema ise isiklikult kontrollib või isegi valitseb - teatavate menetluste abil - mingeid üleloomulikke jõude (vt Frazer 1994: 48-60). Niisiis on küsimus erinevas subordinatsioonis, selles, kes kellele allub, religioossetes võimusuhetes. Religioosne inimene annab end min- 
gite jõudude käsutusse, maag usub end ise mingeid jõude käsundada suutvat. Ma ei ole nõustunud seda tüüpi lähenemisega, sest see viib paratamatult maagia väga praktilis-rakenduslike tõlgendusteni, maagia taandamiseni kratitegemisekunstiks, millekski kohati väga pragmaatilis-manuaalseks. Kui religioosne inimene otsib kontakti transtsendentsusega, siis maag on selles vaatepiiris justkui tehnik, tehnoloog, äärmisel juhul algelise eksperimentaalteaduse esindaja, kes arvab teadvat mingit valemit või menetlust, et esile kutsuda soovitud tagajärge ümbritsevas. See (triviaalmaterialistlik) külg on maagial samuti ja eelkõige hästi silmatorkavalt olemas, kuid see iseenesest ei ole veel kõik, mida saab öelda maagilise elutunde kohta, ja isegi mitte esmane tõsiasi maagiast arusaamisel. Et teatav paradigmamuutus on maagia mõistmisel mõnda aega juba toimumas, seda tõendavad muu hulgas uuematesse teatmeteostesse jõudnud tendentsid, kus maagia ja religiooni vastandamise asemel eelistatakse käsitleda maagiat religiooni ühe osana (vt nt O'Connor 1997: 526-527).

Määratlen maagiat järgnevalt. Saab rääkida maagilisest elutundest ja maailmapildist, nagu ka religioossest elutundest ja maailmapildist, ehkki see viimane ei ütle ilma täpsustusteta (kristlik, taoistlik jne) veel midagi. Õieti võib maagiat võtta kui maailmapildi teatavat aspekti, mis mõnikord saavutab domineeriva rolli (siis saab rääkida maagilisest maailmapildist) ja avastada igas religioonis oma maagiline aspekt, kui ka näiteks kristlus maagiamõistet - ajaloolistel põhjustel - paaniliselt endast eemale tõrjub. Maagia ei ole selles mõistepiiris ühe asja mõjutamine teise asjaga (võluvormelite, rituaalsete menetluste, nõiakunsti võtetega) põhjuse ja tagajärje olemuselt füüsikalisel, mehhaanilisel printsiibil (või sellise mõjutamise printsiipi vääralt uskudes), niisiis lineaarselt. Maagia puhul on asi ennekõike asjade alustrajavas substantsis, mida varasemates kultuurides tõlgendatakse sageli hingena, õigemini - hinge erinevates väljundites, ja just sedakaudu käib tema tihe ühendustee eestigi muistsele kultuurile omase animismi ehk hingedeusuga. Maagiline elutunne ei pea alati tingimata seostuma animismiga, kuid animismil on ilmselt tugev kalduvus siduda enesega maagilise kontaktsuse printsiip.

Kõige lühemalt öeldes: maagia on hinge kehaliste väljundite mitmekesisus ruumis. Kehaliste väljundite all mõeldakse kehalisruumilist eksistentsi kõige laiaulatuslikumas mõttes, seega nii elusolendite kehasid kui ka (meie mõistes) elutuid füüsilisi kehasid, ese- 


\section{Jaan Undusk}

meid ja asju, aga samuti sõnamaagilisi väljundeid, mis avalduvad kas suuliselt, inimkeha füüsilises tegevuses, lausumises, posimises või on ladestunud mingisse teise kehalisusse, olgu või paberkandjale, puule, kivisse. Tasub vaid meeles pidada, et rangelt võttes välistab animistlik maailmavaade nn elutud kehad, s.t sellised asjad, millesse hing juba põhimõtteliselt nagu siseneda ei saakski. Hingedeusku maailmas esineb ainult ajutiselt, mitte põhimõtteliselt elutuid kehi. Hing võib sisse minna igasse füüsilis-ruumilisse kehandisse, aga samuti igast sellisest mingil hetkel väljuda. Surnud inimesest, laibast, on hing küll põhiliselt väljunud (hinge hääbuvaid omadusi säilitab see üha väheneval määral kuni lõpliku määndumiseni), aga miski ei keela teda (või mõnda teist hinge) sellesse taas sisenemast, kui vastav tuju tuleb. Just säärastel ootamatutel sisenemistel põhineb ju terve uskumuste kompleks. Ja just säärane hinge põhimõttelise sisenemise võimalikkus lubab rääkida animistliku maailma kõikhingestatusest: see ei tähenda veel, et kõigel peaks igal jumala hetkel olema hing sees, kuid see tähendab, et kõigesse võib hing igal hetkel põhimõtteliselt siseneda.

Niisiis, maagia ei ole muud kui ühes asjas (kehas) oleleva hinge ülekand(u)mine mingisse teise asja ja seega ühe asja eksistents mingi teise asja kaudu. Üht asja mingi teise asja kaudu elades on teda alati võimalik ka pisut teistmoodi elada, teda teiseks elada, ehk lihtsamalt, ehkki mitte täpselt öeldes - teda mõjustada, ning seega on siia kaasa haaratud ka traditsiooniline mõjustamise motiiv. Aga ei mõjustata mitte kausaalselt, põhjuse-tagajärje printsiibil, vaid nii-öelda hingelise ülekande alusel, hinge mingis teises füüsilises kehandis teistmoodi läbi elades. Niisiis on keha ja hinge mõjuseos vastastikune ning hing kohaneb igasse uude kehasse sisenedes selle keha omapäraga. Hing kehastub igas uues kehas uutmoodi ja keha hingestub iga uue hinge sissetulekul taas endisest erinevalt. Erilisi komplikatsioone põhjustab see, kui ühte kehasse on sisestunud mitu hinge; sel juhul vaheldub nähtuste amplituud tavalisest haigusest kuni romantiliselt lõhestunud isiksuseni. Oluline on kogu protsessi juures ka see, et hing ei allu nii-öelda materiaalse separaatsuse sunnile, s.t selleks, et minna mingisse teise kehasse, ei pea ta tingimata oma eelmisest kehast lahkuma (ja see keha ei pea surema), vaid ta saab neis mõlemas olla samaaegselt (multilokatsiooni printsiip, mis toimib ka katoliku kiriku transsubstantsiatsiooni-õpetuses). Hing nii-öelda avaneb samaaegselt ka mingis teises ruumis, mingis teises kehas või isegi mitmes 
teises kehas, kandub ühte kohta paigale jäädes ühtlasi ka kuhugi mujale, ja just seda peetakse silmas ülaltoodud formulatsiooniga, et maagia on "hinge kehaliste väljundite mitmekesisus ruumis". Hing elab, ruumimetafoori kasutades, mitte kolme-, vaid nelja-, viie- või minupärast kas või kuuemõõtmelises ruumis - numbriline suurus ei oma hingelises reaalsuses mingit tähtsust.

Selles mõttes on ka ristiusul oma maagiline aspekt lausa põhiliste dogmade tasemel: sõna lihakssaamine (inkarnatsioon), transsubstantsiatsioon (leiva ja veini olemusmuundus Jeesus Kristuse ihuks ja vereks) katoliku missal, luterluses eriti jumala vaimu kohalolek pühakirja tekstis. Samuti on Vana Testamendi lauluraamat läbivalt nimemaagiline ning palvetamises aktualiseerub maagilise kontaktsuse printsiip. Õigeusu teoloogias ja õigeuskliku kultuuripiiri keelefilosoofias omandas aga 20. sajandi esimesel poolel ülima tähtsuse ja põhjustas teravaid diskussioone nn imjaslavije (eestseisjaiks muuhulgas Sergei Bulgakov, Pavel Florenski, Aleksei Lossev), s.t usk jumala nime olemuslikku energiakandvusse. Vähemalt P. Florenski rääkis sellega seoses avalikult ka maagilisusest üldreligioosses mõttes, "elava inimese hingestatud suhtlemisest elava loodusega", nähes põhimõtteliselt üht ja sedasama tunnetuslikku tungi nii paganlikus kui ka kristlikus nimekultuses (vt nt Florenski 1998: 270-272).

See, kuidas maagia traditsiooniliselt kitsas ja pragmaatiline käsitus ahistab maagilise kultuuri mõistmist, paistab välja ka neist terminoloogilistest raskustest, millega maadleb O. Loorits oma suurteoses Grundzüge des estnischen Volksglaubens. O. Loorits on kindlalt veendunud kahes asjas: esiteks selles, et eesti rahvausk oli maagilise põhiplaaniga ja eestlase vana maailmapilti sidestas maagilise kontaktsuse printsiip, ning teiseks selles, et süstemaatiline praktiline maagia ja manipulatiivsed nõidumistehnikad - siinses pruugis ka kratitegemisekunst - on Eestis suhtelist hilist ja laenulist, s.t germaanilist päritolu. Et mõiste on mõlemal juhul üks, võib jääda mulje, et $O$. Loorits räägib iseendale vastu. Tegelikult kasutab ta maagiamõistet eesti rahvausundi vanema kihistuse iseloomustamisel laias maailmavaatelises mõttes, nõidumisest rääkides aga üldlevinud - ja lausa taunivas - tehnoloogilises tähenduses. Selline lõhestatus häirib ka tema mõnesid teisi kirjutisi. Programmilises artiklis Maagilisest mõtteviisist (1940) näib O. Loorits üsna lohakalt kokku segavat J. Frazeri ja varase Lucien Lévy-Bruhli seisukohti, tempides saadud tulemust veel ajastu sündmustest stii- 


\section{Jaan Undusk}

hiliselt välja kasvava poliitilise ideoloogiaga (maagia kui totalitaarse, loogika kui vaba demokraatliku ühiskonna sideaine), mistõttu jõuab maagia suhtes ebameeldivatele järeldustele, seda hoolimata ka oma spontaanselt soojast suhtumisest "maagilisse" rahvakultuuri (Loorits 2000: 285-299). Grundzüge'st võime lugeda, et juba eesti rahvausundi uurali aluskihis, kus O. Loorits näeb läbivalt valitsevat maagilist mõtteviisi (die magische Denkweise), oli algupärasena olemas veendumus asja nime ja olemuse orgaanilisest seotusest, mistõttu nime mainimine lõi maagilise kontakti nimetaja ja nimetatu vahel; et kõik uurali rahvad tunnistasid hääle ja laulmise maagilist mõju; et sõna üleüldse sisaldas võimu, millel oli maagiline toime (Loorits 1949-1957 I: 198, 224, 228 jm; vt ka Loorits 1951: 61; Loorits 1990: 31-32). Teisalt saame sealtsamast teada, et ehkki soomeugrilased tundsid lihtsamaid maagilisi toiminguid juba iidsetest aegadest, peab komplitseeritumaid maagilisi menetlusi ehk tegelikku "nõiakunsti" (Zauberei), nagu ka sõnamaagiat, pidama sakslaste kaudu imporditud võõrlaenuks (Loorits 1949-1957 I: 42 jm). Kontuurid jäävad säärastes võrdlustes, rääkimata juba arvukatest üksikväidetest, üsna ähmasteks. Tähelepanelik lugeja saab asjast enam aimu siis, kui ta leiab üles alljärgnevat laadi konkreetsemaid vastandusi kätkevad kirjakohad: tänane eestlaste sõnamaagia on küll uuemat sorti importkaup, usk sõna jõusse aga iidvana ja paljud kõnekäänud teisendavad lihtsalt soove, mille täitumist ei loodeta mitte kindlate maagiliste menetluste kaasabil, vaid pelgalt asjakohase olendi nime nimetamisel; säärased ütlused ja manamised baseeruvad niisiis täielikult nimehingekujutelmal (s.t animistlikul veenelJ. U.) ja eeldavad, et nimetamine tagab soovitud kontakti nimetatava olendiga (Loorits 1949-1957 I: 230). Asjad, mida O. Loorits oma teoses implitsiitse järjekindluse, kuid eksplitsiitse ebapiisavusega vastandab, on seega ürgeestilis-üldvaimne maagiline elutunne ja saksapärane maagiline praktitsism. Muidugi võib säärases vahetegemises oletada ka teatavate ideoloogiliste eelarvamuste kajastusi (vrd ka Loorits 1939: 123-124). Looritsa ideede sõiduvees näib siin liikuvat muuseas August Annist (vt nt Annist 1969: 63).

Teine aspekt, mida O. Loorits ei arenda välja piisava täpsusega, on terminite maagiline ja müstiline vahekord. Mõiste maagiline mõtteviis sünonüümina kohtame tal mõnikord ka mõistet müstilis-maagiline mõtteviis (mentaliteet) (Loorits 1949-1957 I: 42; III: 495 jm). Siingi peegeldab O. Looritsa tekst väga laialt levinud terminoloogilist logedust, millele on tunnuslik maagilise ja müstilise kasutuse- 
levõtt umbmääraste populaarsete sünonüümidena. Ehkki maagilised ja müstilised tunnused teineteist polaarselt täiendavaina tõepoolest koos võivad esineda, on tegemist - nagu siinkirjutaja varem näidata püüdnud - kultuuritüpoloogiliste opositsioonide ja teineteisele risti vastanduvate keelefilosoofiliste protseduuridega. $\mathrm{Ka}$ O. Loorits tajub mõistete erinevat sisu ja vabandab oma laenatud "müstilis-maagilist" mõistetarvitust siin-seal välja mööndustega laadis eestlastele on vägagi omane mediteerivus, mis ei ole neid aga lähendanud müstikale (Loorits 1949-1957 III: 470; vt ka samas III: 257; vrd aga Loorits 1951: 39, kus jutt käib soomeugrilaste müstilispoeetilisest loodusfilosoofiast, või Loorits 1951: 82, kus leiduvad vihjed soome müstilisele usutundele).

Ka maagial ja maagial on kahtlemata vahe, kui võtta vaatlusse ühelt poolt paganlik, animistlik, hingedeusku, teisalt kristlik maagia. Printsiip ja probleem on mõlemal juhul üks - hinge ülekanne. Ent milline on see hing mõlemal üksikul juhul? Hingedeusku inimese jaoks on vähemalt põhimõttelise võimalikkusena kõik kohad hingi täis, piltlikult kõneldes istub igas puus ja kivis ja pudrutükis oma hing sees. Hingedeta pole asjades ei elu ega maailmas liikumist, vähe sellest, mateeria, millest hing välja tuleb, laguneb otsekui oma aristotelliku vormi (entelehhia) kaotanult laiali. Iga elulise probleemi sisuks on hinge õige, positiivse tulemiga ülekanne ja see saab teoks kas ühe inimese või terve kogukonna isiklikul initsiatiivil ja vastutusel. Maksab ainult omavaheline hingeliste ülekannete tulemuslikkus suletud maailmas. Kõik maailmas toimuv on kirjeldatav hingeliste ülekannete summana ning pole olemas mingit maailmast väljas asuvat kõikvägist persooni, kes juhiks hingede tegevust.

Kristlik maagia on selles mõttes midagi muud. Siin saab kellelegi maagilise jõu anda ainult ühe hinge ülekanne - ja see üks on loomulikult monoteistlik jumal ise. Ainult jumalikul (jumaliku hinge) jõul, sellelt saades või sellelt ärastades, on maagiline manipulatsioon võimalik, inimesel endal, ühelgi teisel olendil-esemel iseenesest maagilist imeväge ehk hingejõudu kasutada pole. Me teame, et eristatakse valget ja musta maagiat ja et kristlikus kultuuripiiris on tegeldud, seda muidugi negatiivses mõttes, eelkõige just musta maagia ehk nõiakunstiga. Maagia tundub kitsalt kirikliku meelelaadiga kristlasele õieti alati mustana, sest ta näeb selles jumaliku väe salakavalat usurpeerimist inimese poolt, inimese tahet haarata enda valdusse jõude, mida ta loomu poolest ei ole pädev 


\section{Jaan Undusk}

käsundama. Musta maagi jõud tuleneb kokkuleppest saatanaga, seda küll, kuid saatangi on vaid langenud ingel, s.t jumala endine tagurlik lähikondlane, kelle jõud pärineb algselt jumalast ja kes lõppude lõpuks tegutseb vaid jumaliku lubakirjaga ning tema plaani huvides ("kurja kavatseb, kuid korda saadab head"). Saksa dominiiklase Heinrich Institorise (Krameri) koostatud Nõiahaamer (Malleus maleficarum, 1487), ${ }^{2}$ nõiausu konstitutsioon ja koodeks, rõhutab seda seika äärmise pealekäivusega: ükski nõid ei manipuleeri hingedega omast jõust.

Niisiis, kui hingedeusku maailmas saab maagiline sündmus teoks kõige olemasoleva nii-öelda omavahelise asjaajamise käigus, siis kristlikus maailmas tagab selle teostumise lõppkokkuvõttes vaid monoteistlik maailmaväline jõud, ka siis, kui see toimib usurpeeritud kujul reeturite, taganejate ja vastaliste käes.

Mis meid järgnevalt eelkõige huvitab, see on keelekasutus hingedeusku maailmas. Niisiis istub siin põhimõttelise võimalikkusena igal asjal oma hing sees. Asja hinge üks väljundeid on paljudes maagilistes uskumustes ja seda ka vanas eesti rahvausus teatavasti tema nimi (vt Loorits 1949-1957 I: $198-250 ; 1990: 29-33) .^{3}$ Nimi on üks hinge kehastusi või väljundeid tema igakordsest põhikehast teisal, üks olulisemaid maagilisuse avaldusi. Kui ka kristlikus ilmas on nimi määratu tähtis, siis seal taas üle teiste kumava aupaistena eelkõige üks, kõige ülema ehk alustrajava hinge, jumala nimi, mida müstilises traditsioonis ei saagi küll inimkeeli välja öelda ja millega liitub mitmete teiste pühanimede kobar (Neitsi Maarja jne), samuti kõik teised mõeldavad nimed. Iga üksiku nime pühadus, väärikus ja väärtus tuleneb sellest, et ta on ainujumala nimel nii-öelda ristitud, et ta on selle analoog inimlikus elusfääris ja osutab sümboolsel moel tagasi kõigi nimede pühale algusele. Inimese nime kaudu kõnetatakse iga üksiku inimese jumalikku algupära, kõnetatakse jumalikku loodust tema igakordses personaalses avalduses. Ära võta jumala nime ilmaasjata suhu, manitseb kristlik katekismus, sest see on püha väge täis ja tulemus on ettearvamatu. Kõik moraalsed keelud ja load, mis reglementeerivad ülejäänud nimede kasutamist, lähtuvad inimlike nimede analoogiapotentsiaalist ülima nime maiste teisikutena. Asja tuum ja taust on ristiusus alati jumala nimi.

Niisiis taandub kristlik nimeproblemaatika viimaks üheainsa nime varjatud ja varjamata, otsesele ja analoogsele tarvitusele ning on selles suhtes veel küllaltki lihtne, võrreldes olukorraga paganli- 
kus hingedeusus. Väga vulgariseerivalt öeldes: hoiduda kuritarvitamast ühte nime on veel suhteliselt lihtne. Aga mida peab tegema hingedeusku inimene, kes tunneb, et igas asjas istub võimalust mööda oma isiklik hing sees ja et iga sõna, millega ta kõnetab maailma, toob kaasa kokkupuute hingega? Teisisõnu: kuidas on animistlikus maailmas võimalik rääkimine? See ei olegi ju muud, kui pidev asjade hingedel kõndimine, hingedega ümberkäimine, lakkamatu hingeklahvidele vajutamine, võõraste hingede näppimine. Kui jätta välja keele nii-öelda süntaktiline masinavärk, tema süsteemiloov sideaines, siis on kõik nimefunktsioonis sõnad maagilises seongus hingedega. Kui kristlikus maailmas toimub kõik ühe nime jõuväljas, siis hingedeusku maailmas levitab iga nimi enda ümber omaenda väge ja kontakt hingedega on siin palju vahetum. Kui kristlane ütleb: ära võta ilmaasjata suhu jumala nime, siis hingedeusklik peaks ütlema: ära võta ilmaasjata suhu mitte ühtainustki nime. Kõik need on väge täis, igaüks neist annab hingelöögi, alati omamoodi ja ootamatu. Hingeline substants on hingedeusku maailmas kõnelejale alati väga lähedal, ta puutub sellega kokku vahetult.

Mis siit järeldub? Kindlasti see, et hingedeusku maailmas on kõnetegevus, kõnelemine, rääkimine midagi veel hoopis limiteeritumat, ettevaatlikkust nõudvamat, eluohtlikumat - et ta on mingi hoopis teistsugune tegevus kui kristlikus, s.t olemuslikult ühe-nimemaailmas. Kõnelemine animistlikus keskkonnas on katkematu hingede väljakutsumine, võiks öelda isegi - lakkamatu väljakutse hingedele, seetõttu peab alati enne ütlemist mõtlema, kas üldse tasub öelda või on targem vagusi püsida. Iga sõnaga häiritakse asjade hingi, olgu siis heas või halvas mõttes, aga enamasti ei tea keegi elulises situatsioonis ette, missuguseks võib kujuneda selle häirituse tagajärg. Sõna on tegu, asja nimetades on selle hing juba väljas, ta sirutub kuhugi, kandub kuhugi mujale ja temaga peab midagi peale hakkama. Hinge vale väljakutse põhjustab haigust ja muud õnnetust. Lobisemine kui selline pole võimalik. Et keelt kasutades suheldakse esmajoones hingedesfääriga ja alles teises järjekorras inimestega omavahel, siis on loomulik, et inimlik-keeleline suhtlemine on pärsitud ja vabal või vaimukal, lõdval või lõbustaval inimlikul keskustelul puudub see põhiliselt positiivne oreool, mis tal on mõnes teises, suhtluskesksemas kultuuritüübis. Nii sünnivadki nn vaikuse kultuurid, kus kehtib põhimõte "rääkimine hõbe, vaikimine kuld" ja kus liberaalpedagoogiline printsiip "räägi inimesega, tee talle head" mõjub otsekui ketserluse lipukiri, sest mitte keegi ei 


\section{Jaan Undusk}

oska kunagi ette öelda, kas rääkimise tagajärg saab olema hea või halb. Sõnas on samapalju stiihiat kui metsikus looduses eneses.

Muidugi - võib vastukaaluks väita - olid ka hingedeusku maailmas olemas keele erinevad kasutustsoonid: teatud olukordades, rituaalse tegevuse juures, pühapaikades, kalal ning jahil jne oli keele maagiline tundlikkus suurem, rutiinsetes igapäevastes pisiasjades seevastu väiksem. Ent keskeltläbi võttes pidi see tundlikkus jääma mis tahes olukorras suhteliselt kõrgeks.

Me tunneme sõnamaagilist kultuuri kirjapanduna kõige lähemalt kahest allikast: need on Vana Testament ja soome eepos Kalevala. Üks neist väljendab peamiselt monoteistlikke tunge, teises on tajutav hingedeusklik sügavus. Mõningase liialduse kaasabil võib isegi kujutleda, et vanaheebrea ja soome sugu rahvaste, sealhulgas eestlaste muistne usund olid kaks maagilise kultuuri sammast Euroopa ääremaadel. Nii Kalevala kui ka Vana Testament näitavad, milline vastutus lasub maagilise paine all oleva keele kasutajal. Kalevalas saadab pea iga sõna, mis rääkija suust kukub, mingi füüsiline muutus ümbritsevas elukeskkonnas, sõnaloome on ühtlasi maailmaloome. Esineb suuri maagilisi loojaid nagu Väinämöinen, kuid ka iga teine peab arvestama sellega, et sõna on vanem ja vägevam kui tema ise ning maailma kõikhingestatusega paratamatus seoses. Siin on tühjade sõnade tegemine välistatud - ja seda mitte moraalselt, vaid nii-öelda ontoloogiliselt.

Iseloomulik, et Martin Buber, juudi filosoof, hassidismi ja kabala uurija ning Vana Testamendi saksakeelse tõlke autor, sai ka just Kalevala uuesti tõlkijaks saksa keelde (1914), seejuures Kalevala kui maagilise sõna eepose vaimustunud eestkõnelejaks Lääne-Euroopa ruumis. Oma järelsõnas eepose tõlkele kirjutab ta muuseas:

Raske on leida rahvast, kelles usk sõna - salajase ürgalgupärase sõna-võlujõusse oleks juurdunud nii sügavalt kui soomlastel. [---] Sõna on elementide isand; kes teda valdab, saab luua ja hävitada, saab Kurja kütkendada ja jumalaid endid oma tahtele allutada. Ta laulab oma vaenlased kiviks ja aheldab metselajad; tapab pakase ja riisub talt tema riided. [---] Soomlaste eepos on kogu oma laadilt maagiline: mitte jumala, vaid inimese vägi annab talle tema ainulaadse koe. Soome jumalad on kujult ähmasevõitu, isikliku tahteta, omakoosluseta, ajaloota; kõik, mis nad kuuldavale toovad, saab olemusliku alguse maagilises tegevuses, mis nende üle valitseb. [---] Ja ka kangelase lugu pole taas muud kui maagiliste sünd- 
muste ahel. Asjade võim ja võluri ülemvõim - see on eepiliste runode aines. [---] Olemuslik tegu soome eeposes on sõna (Buber 1968: 388, 393).

Pean seda juudi maagia ja müstika asjatundjas ärganud erihuvi soome eepose vastu väga tähelepanuväärseks. Oma "maagiliselt" teritatud võõrvaatleja pilgul näeb ta asju, millele osutamine soome või eesti rahvalaulus pole ju iseenesest mingi uudis (nn laulu võimu motiiv), kuid mida nii ühemõtteliselt fookusse seada ja maagilise elutunde üldistusena välja käia polnud lähemalt kaejad - võibolla et ka oma orgaanilise kontekstikuuluvuse tõttu - enne M. Buberit osanud või tahtnud. Teatavaks teetasandajaks võis M. Buberile saada itaallane Domenico Comparetti, kes oma uurimuses "Kalevalast ehk soomlaste traditsionaalsest luulest" (1891, saksa keeles 1892) jõuab loitsude (üle)tähtsustamist Kalevala kokkupanus analüüsides isegi mõisteni loitsueepos. Eesti folkloristikas on maagiakeskset vaatlusviisi praktiseeritud vaid erandkorras mõne uurija poolt; lisaks O. Looritsale tasub nimetada August Annistit, kes juba 1930. aastail võttis eesti rahvalaulu poeetilise printsiibi tähistusena kasutusele mõiste maagiline metaforism (Annist 1935: 324-326; Annist 1936: 786-788). ${ }^{4}$ Laulik (või tema loo järgmine edasilaulja), seletab A. Annist oma mõiste uuesti lahti aastakümneid hiljem, ikka neidsamu 1930. aastate formulatsioone korrates, hakkab nagu ise uskuma oma puhtsõnastuslikke luulepilte, ainult võrdluseks mõeldud pilt kasvab omaette ehitusmotiiviks. See loob olukorra, milles kunagi pole selge, kus just meile sugereeritud "piltlik väljendus" lõpeb ja tõesti mõeldud nõiduspärane reaalasi või reaalsündmus algab (Annist 1969: 197). A. Annisti jaoks tekib maagiline metaforism niisiis piiritsoonis, kus pole võimalik öelda, kas objektile antud uus nimi tähistab tema kujundlikku rakendust uues poeetilises funktsioonis või kajastab see n-ö tõepäraselt objektiga tegelikkuses toimunud moondumisi (kui mehetapjast Maiest saab rahvalaulus angerjas meres, siis pole üldsegi selge, kas märgib see allegooriliselt Maie endauputamist merre või seda, et ta tõepoolest moondus reaalselt kalaks). A. Annisti maagilises metaforismis on sedasama kafkalikku sisu, mis hilisemas kirjandusteaduslikus, peamiselt ladinaameerika kirjandusega seoses tarvitatud mõistes maagiline realism.

Keelemaagial on aga ka teine pool, juhul kui võtame arvesse, et kõnelemine ei saa isegi "vaikuse kultuuris" piirduda ainult sõnumise, posimise ja nõidumisega, s.t pideva ja tohutu keelelise vastutuse kandmisega. Mida teha siis, kui tahetakse end mõnikord veidi 


\section{Jaan Undusk}

kergemalt ja vabamalt väljendada, mitte sakraalse raskuse, vaid pigem profaanse kergusega? Niisiis mitte nõiduda, vaid niisama ennast väljendada, end emotsionaalselt välja elada, oma kuuldutnähtut luuleliste sõnadega kokku võtta? Kuidas on see maagilises kultuuris võimalik? Või kas üldse on võimalik? Kuidas on maagilises kultuuripiiris võimalik sõnakunst kitsamas mõttes, mis eeldab ju alati teatavaid mängulisi vabadusi? Või ei olegi see võimalik ja kõik on vaid otseselt ellu puutuv tegu?

Maagiline kultuur on ise välja töötanud võimaluse end pideva maagilise paine alt vabastamiseks. See saab teoks asendusnimede, eufemismide või isegi üldisemalt - salakeele tarvituselevõtus. Asendusnimel puudub maagiline jõud, sest ta pole asja hinge väljundeid, vaid seda asendav puhtkeeleline märk. Niisiis, lobiseda, ilutseda, "kuntsi teha" on ikkagi võimalik, aga kui tahetakse seejuures hoiduda maagilise keelekasutuse ohtudest, nõidumise ettearvamatutest kõrvalnähtudest, siis peab tarvitusele võtma asendusnimed. Nendega on muidugi samuti omamoodi häda. Esiteks, neid peab uuendama, sest eufemism võib juurduda pika kasutuse tagajärjel asja hinge, omandada pärisnime tunnuseid ja ühtlasi kaotada oma eufemistliku immuunsuse (hing hakkab teda ära tundma ja temale "vastama"). Teiseks, puhas-eufemistlik sõnakasutus ei paku iseenesest ka esteetilist lõbu. Kunst puhtas salakeeles ei ole võimalik (vt ka Undusk 1989: 978), sest teatav maagiline mõjukomponent või sisenduspotentsiaal peab saatma tedagi.

Sellest järeldub, et juhul kui ei taheta esmajoones sõnuda, lausuda, hingi välja kutsuda, vaid kasutada sõna vabamatel esteetilistel eesmärkidel, tuleb päris- ja asendusnimesid maagilises kultuuris väga täpselt proportsioneerida: tuleb küll pärisnimedest suuresti hoiduda, et üldse tekitada kunstilist mänguruumi ja tagada endale vabadus sõnaga manipuleerimiseks, aga samas tuleb pärisnimesid ometi kaasa haarata, sest puhtasendusnimeline keelekasutus muutub pinnatuks verbaalseks mänguks ega avalda kuulajale enam mingit, ka mitte esteetilist mõju.

Olemegi jõudnud eesti vanema lüürilise ehk regivärsilise rahvalaulu juurde. Ma võtan eelneva põhjal seega eelduseks, et eestlaste muistne sõnalooming on võrsunud suuresti hingedeusku sõnamaagilises keskkonnas. O. Looritsa järgi toimus kiire üleminek maagiliselt mõtteviisilt loogilis-ratsionalistlikule alates 19. sajandi keskpaigast (Loorits 1949-1957 III: 363; 500). Muidugi on pealetungiv kristlik elutunne avaldanud oma vastutoimet juba varem, kuid 
et hingedeusk, kristlikus keeles ebausk, ka kristianiseeritud eestlaste juures pikka aega väga tugev säilis, selle kohta on tõendusmaterjali piisavalt. Kui muistne eesti kultuur oli domineerivalt maagiline, siis peaks seda kajastama ka rahvaluule, isegi juhul, kui tegu ei ole mingite väga ürgsete loomeproduktidega. Tunneme maagilisi motiive rahvajuttudes, samuti muus suulises pärimuses. Rahvalaulude puhul tuuakse näiteks enamasti loitsud (ja loitsulisus üleüldse), s.t otseselt maagilised salmid kui vanimasse kihistusse kuuluv lauluvara.

Siiski oleks loogiline arvata, et maagilise kultuuri märke ei kandnud mitte ainult otsekohene maagiline loits, vaid ka ülejäänud osa rahvalaulust, milles keskkonna üldine maagiline sund pidi tahestahtmata kuidagiviisi avalduma. Pakun välja hüpoteesi, et üks tähtsaid maagilisi kultuuri rudimente ka mitte otseselt maagilises laulus ongi meile kõigile tuntud parallelism ehk mõtteriim, mõtte varieeritud kordus, eesti rahvalaulu vahest et kõige kergemini äratuntav väline iseloomustaja. Pole ehk tähtsusetu asjaolu, et just vanaheebrea ja muinassoome luule, need kaks valdavalt maagilises kultuuripildis võrsunud tekstikogumit tuuakse kõige sagedamini näiteks, kui jutt käib parallelismist sõnaloomingus. Vanaheebrea luule juhtis eurooplase tähelepanu üldse esimesena parallelismile kui vorminähtusele (Robert Lowth 1753), Kalevala on koht, kust nopitakse sageli kõige esinduslikumat näitematerjali mõtteriimi seaduspärasuste tundmaõppimisel.

Parallelismile on antud mitmeid seletusi. On räägitud tema mäluja esitusfunktsioonist, parallelismist kui meeldejätmise ja inspiratsiooni vahendist valdavalt suulises kultuuritüübis. Sedalaadi enamasti ratsionalistlikke seletusi esindab näiteks Johannes Aaviku poolt antu:

Parallelism on sellest tulnud, et laulik omal ajal laulud otsekohe (improviseerides) lõi, ja sellal kui kaaslauljad ta loodud sõnu kordasid, sai ta aega uusi mõelda. Kui tal aga uus mõte kohe ei tulnud meele, heietas ta sama mõtet edesi, kuid teiste sõnadega, kuni tal uus mõte tuli ja laulu võis mõtte poolest jätkata (Aavik 1919: 168).

On räägitud vaatepunktide vaheldumise parallelistlikust põhimõttest mõistelise koondkujutelma tekitamisel, niisiis parallelismi tunnetuslikust rollist. Robert Alter, piiblipoeetika parimaid tundjaid, käsitleb parallelismi mitmekihilise teoloogilis-retoorilise võimendusvõttena (Alter 1981: 88-113; 1989). 


\section{Jaan Undusk}

Tartu Ülikooli juures alustati 1950. aastail nähtavasti ulatuslikumaid süstemaatilisi parallelismialaseid uuringuid, mis ei andnud nii suurejoonelisi lahendusi, kui algselt oodatud, aga siiski mitu kohati heal tasemel artiklit (Koemets 1955; 1963; Kubjas 1957). Laine uus tõus on täheldatav 1970.-1980. aastail, mil parallelismist kirjutasid Jaan Kaplinski ja Helle Metslang. J. Kaplinski oletab, et parallelism on mütoloogilisele teadvusele omaseid abstraheerimisvõtteid, mis annab võimaluse tõusta kõrgemale päris argikonkreetsusest, minetamata siinjuures konkreetse väljenduse korvamatut kujukust (Kaplinski 1972: 137). Olulisim J. Kaplinski poolt esile toodust on mõte tõelise parallelismi alatisest disjunktiivsusest ehk paralleelvärsside omavahelisest või-seosest, mis tähendab seda, et paralleelvärsside vahel ei saa regilaulu poeetilises süsteemis rangelt võttes tekkida ei samatähenduslikkuse ega vasturääkivuse suhteid, sest värsid on alati reastatud mingi avatud valiksarjana, mille liikmed on suhteliselt sõltumatud ja mille sihiks määramatuse kaudu loodav abstraheering.

Arvatavasti ongi parallelismi disjunktiivsus vahend, millega rahvalaul saavutab vajaliku abstraktsuse ja määramatuse, jäädes ometi maksimaalselt konkreetseks (Kaplinski 1972: 136).

See parallelistlik määramatuseloome, mida pisut teise vaatenurga alt on nimetatud ka alliteratiivseks häguks, on tähtis lüli siinseski maagiakeskses arutlusketis, ehkki J. Kaplinski esitleb seda mõtlemisvormina ega seo teda usundliku maailmatajuga.

Helle Metslang lähtub Juri Lotmani mõistesüsteemist, kui käsitleb parallelismi keele poetiseerimise ehk sekundaarse modelleerimise vahendina, mis allub samasusesteetika nõudeile (Metslang 1981: 77). J. Kaplinski tunnetusteoreetilise dominandi kõrvale seatakse siin esteetiline põhifunktsioon. Esteetilise iha kaasamine parallelismi seletusse on siinkirjutajagi meelest vältimatu, ent ühes sellega ei ole veel saadud vastust küsimusele: miks rajab see iha enesele vanemas rahvalaulus teed just lüürilise parallelismi kaudu? Miks on just mõtteriimist kujunenud meie regilaulu üks vormilisi alustalasid? On ilmsesti selge, et parallelism ei ole mingi puhasesteetiline vorm iseeneses, mille kunstiline toime tuleneks justkui vahetult tema struktuurist, vaid et tal on oma tunnetuslik staatus (see, mille võtab luubi alla J. Kaplinski), ning veelgi enam - et ta on esteetilis-tunnetuslikuks verbaalstruktuuriks kujunenud mingite kultuurinormide kitsendavas kontekstis. Niisiis tuleks heita pilk 
veelgi kaugemasse spekulatiivsesse tingitusse, leidmaks parallelismile koht maagilis-animistliku maailmataju üldraamis.

Mõtteriimi ühest erivormist ehk nn eitavast (negatiivsest) parallelismist kirjutasid neilsamadel aastatel Felix Oinas (Oinas 1985) ja Paul Hagu (Hagu 1980). Maagilise funktsionaalsuse seisukohalt ei esinda eitav parallelism mingit nähtavat erijuhtu, ehkki toob kohati lõikavamalt esile mõtteriimi J. Kaplinski analüüsitud disjunktiivsuse ja tema allpool vaadeldava eufemistliku laadi (sest iga asjaga seostatav eituste hulk on põhimõtteliselt avaram kui tema jaatuspotentsiaal). F. Oinas ja P. Hagu tegelevad regivärsi parallelistlike struktuuridega jõudmaks välja nende laenulisuse või genuiinsuse sedastamiseni, usutlemata nähtuse universaalsemaid tagamaid.

Viimastel aastatel on märgata parallelismi kui regilaulu juhttunnuse uut tähtsustamist. Kristi Salve peab seda koos algriimiga regivärsi esmaseks määratlejaks, millele alles teises järjekorras lisanduvad silbilis-rõhulised vahekorrad (Salve 1997: 476). Mari Sarv arendab teesi monograafiliselt edasi, postuleerides algriimi ja parallelismi vahelise võrdelise sõltuvuse (parallelism soodustab algriimi esinemust), mis on arhailisem kui värsimõõdu sundus ja mida kaheksasilbilise värsirea normi teke asus pigem jõudsalt lagundama (Sarv 1999). Üldkultuurilise taustategurina paistab Mari Sarv tunnistavat peamiselt esteetilist.

Tulgem siinkohal välja hüpoteesiga, et parallelism kui semantiliselt põnev kordusfiguur on kaksipidiselt seotud algse maagilise sõnakasutusega: nii loitsulis-manavate verbaalstruktuuride kui ka nende esteetilise ülemängimisega, nii sakraalse nimehingekultuse kui ka selle profaanse tasalülitamisega. Ühelt poolt on parallelism muidugi kordus, teisalt midagi sellist, mida võiks nimetada välditud korduseks või asenduskorduseks. Mis parallelismis pealetükkiva sagedusega kordub, see on lausestruktuur, ühel ja samal süntaktilisel positsioonil esinev samasse - ehkki tihtipeale pidevalt laienevasse - mõistehulka kuuluv sõna, esituslikult ka intonatsioon, mis loob hästi äratuntava loitsiva efekti. Samal ajal aga teadvustab mõtteriim millegi hoopis vastupidise, ja nimelt selle, et korrata ei tohi, et kordus kui maagiline võimendus on keelatud. Mitte miski ei aktualiseeri semantilist kordusekeeldu nii ilmekalt kui semantiliste positsioonide kordus üha määramatumaks muutuva sisuga. Selles suhtes saab parallelismi edukalt võrrelda negatiivsele teoloogiale omase retoorilise menetlusega, mille verbaalne peatumatus peab lõppkokkuvõttes toimima otsekui sõnastuskeeld (vt Un- 


\section{Jaan Undusk}

dusk 1998: 26-43 jm). Võtame kas või alguse kõige lihtsamast, igale eestlasele tuntud lasteloitsust, mille Friedrich Reinhold Kreutzwald ja Alexander Heinrich Neus paigutasid oma tuntud kogumikus Mythische und magische Lieder der Ehsten küll maagiliste laulude alla (Kreutzwald \& Neus 1854: 88), kus aga oma osa on juba ka sakraalsust lahjendaval mängumaagial (mis ei tähenda, et see lapse valukohal sõnutuna ei peaks oma mõju avaldama!):

Varesele valu, harakale haigus, mustale linnule muи mure [---]

Peavärsis esitatavad nimed (vares, valu) asendatakse järgnevates värssides samas positsioonis mingite teiste ehk asendusnimedega (harakas, must lind; haigus, muu mure), mille kaar viib põhimõtteliselt poeetilisse lõpmatusse. Vares ja harakas on küll mõlemad mustad linnud ja must lind seega justnagu nende loogiline üldistus, kuid samas võetakse suund kõikide mustade lindude koondhulka, mis pikeneb määramatult. Veelgi näitlikum on lugu värsirea teise liikmega. Valu kui kehaliselt lokaalne vaevus laieneb teises värsireas haiguseks ehk organismi üldkahjustuseks, ning kolmas värss pakub vaat et eksistentsiaalse lõpmatusena välja juba mии mure. Korratakse küll, aga tegelikult mida? Alatakse varesest ja valust, aga liidetakse lõppeks suvalisele mustale linnule mis tahes mure. Variatsioon ei ole sealmaal ranges mõttes enam võimalik, sest elu mustem pool on juba täismahus hõlmatud. Mis üle jääb, see on vaid võimalik kontrast, vastandus, semantilise teisenduse lõpetamine.

Maagilise tekstiloome üks olulisi tunnuseid ongi kordus, nimekordus laias mõttes. Parallelism on kahtlemata kordus just sel määral, kui mitu korda kordub mõtteriimi paralleelvärssides peavärsis esitatud nime asendusnimi, variatsioon. Samas, nagu näeme, võetakse suund korduste arvu piiramatule hulgale (varese ja musta linnu vahele ühelt poolt ning valu ja muи mure vahele teisalt mahub juba määramatu arv variatsioone) ega korrata viimaks tegelikult enam midagi. Pigem võib seda protseduuri nimetada demonstratiivselt välditud korduseks. Maa peale tagasi tulles sedastagem: kui regilaulu esmaseid stiilitunnuseid ongi parallelism, siis on seda teises järjekorras kohe asendusnimede ohtrus, sest üks tingib teist. Paralleelvärsside rohkus on kooskõlas asendusnimede rohkusega. Asendusnimi ehk eufemism aga, nagu ülal tu- 
vastasime, on esmane vastumürk maagiale. Asendusnimel puudub maagiline toime. Seevastu annab ta lauljale teoreetiliselt piiramatu vabaduse poeetiliseks eneseväljenduseks maagilise kultuuri rüpes, kus nimesid (aga see tähendab pea kõike kõneldavat) tuleb suhu võtta ülima ettevaatusega. Eufemismide ja parallelismi omavahelise tingituse on - küll väga põgusalt - ära maininud ka O. Loorits (1949-1957 III: 435).

Niisiis on parallelism huvitav nähtus: ühelt poolt on ta kordusfiguurina selgelt maagilise sõnakasutuse vahendeid, teisalt - asendusnimede viljaka generaatorina - neutraliseerib ta nimemaagiat kõige järjekindlamal moel.

Eesti regilaulu on võrreldes soome omaga nimetatud impressionistlikumaks, naiselikumaks, mängulisemaks, lüürilisemaks jne. Minu oletus, mis vajab veel kontrollimist, oleks järgmine: eesti rahvalaulu mainitud omadused on tingitud paralleelvärssides esinevate asendusnimede suuremast suvalisusest, nende semantilisest hajuvusest, nende vabamast, vähem motiveeritud kasutamisest soome runodega võrreldes. Kui parallelism ühes oma lõikes (kui kordusfiguur) on maagiat jäljendav ja teises seda (asendusnimedega) neutraliseeriv, siis eesti regilaul teeb keskeltläbi kaalukama panuse viimasele. Kohati tundub, et tavalises eesti regilaulus peavärssi ja alusnime (seda, mida varieerima asutakse) üldse polegi, alustamise ja lõpetamise koht pole üldse tähtis, mistõttu kõik on variatsioon ja eufemism, igapidi ümberpööratav, ning peaasjaks jääb - vormiliselt võttes - verbaalse vabanemise manifestatsioon:

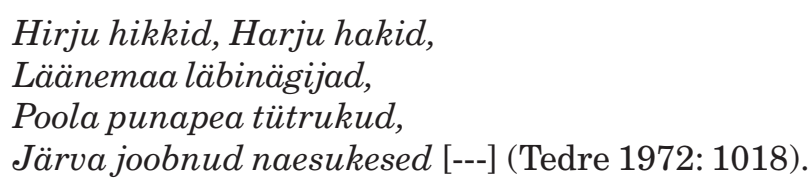

Kas näeb see välja kui poeetiline võimendus? Või mõjub nagu abstraheerimisprotsess? Mingis lõikes võib-olla nii üht kui ka teist. Seda mööndes ei saa siiski eitada, et esimese mulje põhjal on tegemist otsekui maagilise loitsu (tahtmatu) paroodiaga, kus võluvormelid mõtestatakse pikaldases dekodeerimisprotsessis paralleelridasid paljundades - või öelda lausa: maagilise keelekasutuse dekonstruktsioonis - ümber poeetilise lisaväärtuse kandjateks. Fr. R. Kreutzwald viis selle dekonstrueeriva tendentsi Kalevipojas kohati äärmuseni: seal kedratakse paralleelvärsse ja asendusnimesid sellise hooga, et regi- 


\section{Jaan Undusk}

laulu maagiapotentsiaal võib sootuks hääbuda, mis toob kaasa ühtlasi poeesia allakäigu.

Kui on õige, et soome suurema maagilise laenguga rahvalaulu esitasid valdavalt mehed, eesti mängulis-lüürilisemat põhiliselt naised, siis võib metafoori korras rääkida eesti rahvalaulus kajastuvast feministlikust revolutsioonist regilaululise lüürika suunas. Eesti regilaul annab märku üleminekust maagiliselt ekspressiivsele ja esteetilisele sõnakasutusele. Maagilise kultuuri raames lasub igal öeldud sõnal raske paine - see on seotud vastutuse, asjade hinge häirimise ja sellest tulenevate ettenägematute tagajärgedega. Selle sõnalise vastutusekoorma, pideva enesetalitsemise, maagilise orjuse vastu protesteeriski naislaulja, kes tahtis ennast lauldes lihtsalt välja elada, ennast väljendada, niisama "ilutseda" või "kuntsi teha". Ta tahtis end sõna maagilisest painest vabaks laulda ja seda maagilises kordusfiguuris endas peituvate võimalustega. Asendusnimede lüürilise hajuvuse suurendamine seda just lubaski. Asendusnimi oli ohutu, omamoodi kastreeritud nimi - temaga võis manipuleerida vabamalt, vastutust kartmata. Ilutseda, end subjektiivsemalt, inspiratiivsemalt kehtima panna. Me kõik tunneme Jakob Hurda setu teisendeist kompileeritud Ilulaulu:

$$
\begin{aligned}
& \text { Ilu sõitis jõge pidi, } \\
& \text { Laulu laia välja pidi [---] }
\end{aligned}
$$

Ilule tulevad vastu poisid, kelle seltsi ta ei lähe, naised, kelle seltsi samuti mitte - need mõlemad on seotud töö ja kohustustega ning unustavad Ilu kergesti. Küll aga läheb Ilu tüdrukute sekka, sest nondel käib ilutsemine nagunii ette ja taha, nad on vabamad, kerglasemad, ja mitte nii ühiskonna - sealhulgas ka maagilise tabukultuuri kohuslased. Ilulaul on otsekui eesti rahvalaulu lüürilise vabanemise manifest. Sõnast kui maagilisest orjusest on üle saadud, jõutud on sõna kui mõõdukalt maagilise mõnuni. Jaan Puhvel on oma sõnataidurlikul moel rääkinud mahakäinud mü̈̈dist kui eepika taimelavast. Mina võiksin oma arutluse lõpetada sellele sarnaneva motiiviga: mahakäiv maagia kui lüürika taimelava.

\section{Kommentaarid}

1 Ilmunud kogumikus Uurimusi mü̈̈dist ja maagiast. Koost Peet Lepik. Tallinn: TPÜ Kirjastus, 2001, lk 110-134. 
2 Traditsiooniliselt peetakse selle raamatu teiseks autoriks Jacob Sprengerit, kuid uusim saksakeelne kommenteeritud tõlge omistab autorsuse üksnes Institorisele (vt Kramer 2000).

${ }^{3}$ Populaarselt on muistset maagilist keele-eetikat O. Looritsa laadis hiljuti tutvustanud oma artiklis Maria Tilk (1999).

${ }^{4}$ Selle osunduse eest võlgnen tänu Ülo Tedrele.

\section{Kirjandus}

[Aavik, Johannes] 1919. Valik rahvalaule. Valind ja seletavate lisade ning sõnastikuga varustand Johannes Aavik. Tartus: Istandik.

Alter, Robert 1981. The Art of Biblical Narrative. New York: Basic Books.

Alter, Robert 1989. The Characteristics of Ancient Hebrew Poetry. Robert Alter \& Frank Kermode (toim). The Literary Guide to the Bible. London: Fontana Press, lk 611-624.

Anni[st], August 1935. Kalevala kui kunstiteos [2]. Looming 3, lk 315-326. Annist, August 1936. Meie rahvalaulu stiili küsimusi. Looming 7, lk 781-788.

Annist, August 1969. "Kalevala” kui kunstiteos. Tallinn: Eesti Raamat.

Buber, Martin 1968. Nachwort. Kalevala. Wolfgang Steinitz (toim \& tõlk). Rostock: Hinstorff Verlag, lk 387-394.

Florenski 1998 = Флоренский, Павел. Имена. Москва \& Харьков: ЭксмоПресс-Фолио.

Frazer, James George 1994. The Golden Bough: A Study in Magic and Religion. Ware: Wordsworth Editions.

Hagu, Paul 1980. Eitav parallelism regivärsi stiilivõttena. Eesti rahvaluule žanriprobleemid. Tartu Riikliku Ülikooli Toimetised 528. Töid eesti filoloogia alalt VII. Tartu: Tartu Riiklik Ülikool, lk 49-64.

Jakobson, Roman 1966. Grammatical Parallelism and its Russian Facet. Language 2, lk 399-429.

Kaplinski, Jaan 1972. Parallelismist lingvisti pilguga. Keel ja Kirjandus 3, lk 132-145.

Koemets, Aino 1955. Sisu ja vormi ühtsus eesti regivärsilise rahvalaulu parallelismis. Eduard Laugaste et al. (toim). Ajaloo-keeleteaduskonna töid. Tartu Riikliku Ülikooli Toimetised 38. Tallinn: Eesti Riiklik Kirjastus, lk 145-164.

Koemets, Aino 1963. Mõningaid tähelepanekuid parallelismi kohta Kreutzwaldi "Kalevipojas". Eduard Laugaste et al. (toim). "Kalevipoja" 


\section{Jaan Undusk}

küsimusi II. Tartu Riikliku Ülikooli Toimetised 138. Tartu: Tartu Riiklik Ülikool, lk 45-51.

Kramer, Heinrich (Institoris) 2000. Der Hexenhammer = Malleus Maleficarum. Kommentierte Neuübersetzung. Günter Jerouschek \& Wolfgang Behringer (toim). München: Deutscher Taschenbuch-Verlag.

Kreutzwald, Friedrich Reinhold \& Neus, Alexander Heinrich 1854. Mythische und magische Lieder der Ehsten. Sankt-Petersburg: Buchdruckerei der Kaiserlichen Akademie der Wissenschaften.

Kubjas, Alviine 1957. Parallelism J. Hurda rahvalaulude kogus "Vana kannel" I. Eduard Laugaste et al. (toim). "Kalevipoja” küsimusi [1]. Tartu Riikliku Ülikooli Toimetised 53. Tartu: Tartu Riiklik Ülikool, lk 195-215.

Loorits, Oskar 1939. Oma rada: Programmartikleid uue Eesti loomisel 1934-1938. Tallinn: Kuldkiri.

Loorits, Oskar 1940. Maagilisest mõtteviisist. Rahvapärimuste Selgitaja II: 1 (8). Tartu: Eesti Rahvaluule Arhiiv, lk 1-10.

Loorits, Oskar 1949-1957. Grundzüge des estnischen Volksglaubens I-III. Skrifter utgivna av Kungl. Gustav Adolfs Akademien för Folklivsforskning 18: 1-3. Uppsala \& Köpenhamn: Lundequistska Bokhandeln \& Munksgaard.

Loorits, Oskar 1951. Eestluse elujõud. Iseseisvuslaste kirjavara 5. Stockholm: Tõrvik.

Loorits, Oskar 1990. Eesti rahvausundi maailmavaade. 3. tr. Tallinn: Perioodika.

Loorits, Oskar 2000. Meie, eestlased. Hando Runnel (koost). Eesti mõttelugu 35. Tartu: Ilmamaa.

Metslang, Helle 1981. Eesti regilaulu värsiparallelismi lingvistilise uurimise lähtekohti. Jüri Talvet et al. (toim). Värsiõpetuse aktuaalseid probleeme ja soome-ugri värsitehnika küsimusi. Tartu Riikliku Ülikooli Toimetised 587. Studia metrica et poetica 3. Tartu: Tartu Riiklik Ülikool, lk 5080.

O'Connor, Kathleen Malone 1997. Magic. Thomas A. Green (toim). Folklore: An Encyclopedia of Beliefs, Customs, Tales, Music, and Art II. Santa Barbara \& Denver \& Oxford: ABC-CLIO, lk 519-528.

Oinas, Felix J. 1985. Negative Parallelism in Karelian-Finnish Folklore. Felix J. Oinas. Studies in Finnic Folklore: Homage to the Kalevala. Suomalaisen Kirjallisuuden Seuran Toimituksia 387. Uralic and Altaic series 147. Helsinki: Suomalaisen Kirjallisuuden Seura, lk 78-92.

Salve, Kristi 1997. Mõtteid vepsa rahvalaulust. Keel ja Kirjandus 7, lk $470-480$. 
Sarv, Mari 1999. Regilaul: Clearing the Alliterative Haze. Folklore: An Electronical Journal of Folklore 10. Tartu: Institute of the Estonian Language, lk 126-140.

Steinitz, Wolfgang 1934. Der Parallelismus in der finnisch-karelischen Volksdichtung, untersucht an den Liedern des karelischen Sängers Arhippa Perttunen. Folklore Fellows' Communications 115. Helsinki: Suomalainen Tiedeakatemia.

Tedre, Ülo (toim) 1972. Eesti rahvalaulud: Antoloogia 3: 3. Tallinn: Eesti Raamat.

Tilk, Maria 1999. Keelemaagiast. Helgi Vihma (toim). Artikleid ja arhivaale II. Keeleuuenduse Kirjastik B3. Tallinn: Johannes Aaviku Selts, lk 88-94.

Undusk, Jaan 1989. Mõistmine kui pidevus. Akadeemia 4, lk 711-732.

Undusk, Jaan 1998. Maagiline müstiline keel. oxymora 2. Tallinn: Virgela.

Undusk, Jaan 1999. Kuidas tsentreerida lõpmatust: Mõtisklus Felix Oinase raamatu serval. Felix Oinas. Tuul heidab magama ja teisi esseid. Keele ja Kirjanduse raamatusari 3. Tallinn: Keel ja Kirjandus, lk 257-267.

Vesselovski 1989 = Веселовский, Александр. Психологический параллелизм и его формы в отражениях поэтического стиля. Александр Веселовский. Историческая поэтика. Москва: Высшая школа, lk 101-154. 